\title{
Effect of Taxpayer Awareness, Understanding's Knowledge of Taxation on Compliance of Small and Medium Micro Business Taxpayers at Pratama Tax Service Office Cibitung
}

\author{
Agus Subagiyo ${ }^{1}$, Siti Nurbaity ${ }^{2}$, Khikmatul Islah ${ }^{3}$, \\ Rudianto Hermawan ${ }^{4}$, Ahmad Junaidi ${ }^{5}$ \\ ${ }^{12345}$ Institut Ilmu Sosial dan Manajemen STIAMI \\ Correspondent: agussbagiyo@gmail.com¹‥
}

\begin{tabular}{ll}
\hline Received & : August 26, 2021 \\
Accepted & : January 15, 2022 \\
Published & : January 31, 2022
\end{tabular}

Citation: Subagiyo, A., Nubaity, S., Islah, K., Hermawan, R., Junaidi, A. (2022). Effect of Taxpayer Awareness, Understanding's Knowledge of Taxation on Compliance of Small and Medium Micro Business Taxpayers at Pratama Tax Service Office

Cibitung. Ilomata International Journal of Tax and Accounting, 3(1), 68-77.

https://doi.org/10.52728/ijtc.v4i1.380

\begin{abstract}
The number of small and micro business taxpayers at the Cibitung Pratama Tax Office from year to year after the increase, but the high increase in the number of taxpayers is not directly proportional to the increase in taxpayer compliance in paying and notifying the tax. The purpose of this research is to recognize the influence of understanding, the description and knowledge of taxpayers on the compliance of small and medium-sized micro business taxpayers at KPP Pratama Cibitung. The population in this research is a small intermediate micro business taxpayer registered at KPP Pratama Cibitung. The procedure for taking illustrations in this research uses accidental sampling, on the contrary, the collection of information through the questionnaire method. The illustrations used in this research are 100 respondents. In this research, hypotheses are tested using multiple linear regression analysis. The results of this research display that understanding, descriptions, and knowledge of taxpayers regarding partial taxation influence the compliance of small and medium-sized micro business taxpayers in the Cibitung Pratama Tax Office.
\end{abstract}

Keywords: Taxpayer Awareness, Understanding and Knowledge on Tax, Taxpayer Compliance

\section{INTRODUCTION}

Currently, Small and Medium Enterprises (MSMEs) are increasingly showing their existence and able to generate relatively high profits. Last but not least also able to compete in the era of globalization as it is today, but not yet in line with the level of compliance in carrying out its tax obligations (Machmudah, 2020; Syuhada \& Gambetta, 2013; Tambunan, 2019). The level of compliance of small and medium-sized micro enterprises (MSMEs) taxpayers is still fairly low, the target of tax receipts has not been achieved (Rahmadhani et al., 2020; Shafi et al., 2020; Sinuhaji, 2019). Low compliance of taxpayers of Small and Medium Enterprises (MSMEs) is certainly a problem every year (Rahayu, 2019; Susanti \& Widajatun, 2021). In 2013 first applied 
Effect of Taxpayer Awareness, Understanding's Knowledge of Taxation on Compliance of Small and Medium Micro Business Taxpayers at Pratama Tax Service Office Cibitung

Subagiyo, Nubaity, Islah, Hermawan, Junaidi

the $1 \%$ rate, Tax Service Office Pratama Cibitung recorded the lowest tax receipts in Bekasi Regency. Until 2017, the problem of low tax compliance in Bekasi Regency is still experienced today (Rahayu, 2019; Widiastuti, 2017). The number of Small and Medium Micro Enterprises Taxpayers recorded in Tax Service Office Pratama Cibitung as of December 2017 reached 22,567 small and medium-sized micro enterprises taxpayers (Ernita \& Sudjiman, 2021). The increase in the number of Small and Medium Micro Enterprises is not in line with taxpayer awareness in fulfilling its obligation to pay taxes (Andreas \& Savitri, 2015).

\begin{tabular}{cccccccc} 
& Tahun & WP & \multicolumn{2}{c}{ Target Rasio } & \multicolumn{2}{c}{ Realisasi } & Capaian \% \\
No & Pajak & Terdaftar & SPT & $\%$ & SPT & $\%$ & \\
1 & 2015 & 3.953 & - & - & 1.801 & $45.56 \%$ & Infinity \\
2 & 2016 & 4.466 & - & - & 1.740 & $38.96 \%$ & Infinity \\
3 & 2017 & 5.924 & 2.962 & $50 \%$ & 2.500 & $42.20 \%$ & $84.40 \%$ \\
4 & 2018 & 7.131 & 4.635 & $65 \%$ & 3.103 & $43.51 \%$ & $66.94 \%$ \\
\hline
\end{tabular}

Based on table 1, it appears that the realization of taxpayer tax receipts of private persons in the MSME sector has never reached the overall target (Barigozzi et al., 2019; Cozmei \& Rusu, 2015; Savitri \& Musfialdy, 2016). Low level of taxpayer compliance (Tax Compliance) in paying taxes is one of the causes of not optimal tax receipts in Indonesia (Iyer \& Kaszak, 2021; Melando \& Waluyo, 2013). Low obedience levels can be caused by a number of elements of the lack of views and knowledge regarding tax rules by tax repellation, low taxpayer knowledge phase, type of fiskus service, tax sanction, and the use of online tax payment systems or called e-bill taxes that do not known size and understood by taxpayers (ㅂajawiyah et al., 2021; Saad, 2014; von Brasch et al., 2021).

The inhibiting factor that controls the compliance of the compliance with small and medium micro-enterprises (MSMEs) includes: (1) the level of taxation view (2) quality of fiscus services, (3) understanding of the general provisions and community taxation procedures are still low (Batrancea et al., 2019; Chaudhry, 2021; Damayanti et al., 2015).

\section{Theoretical Framework}

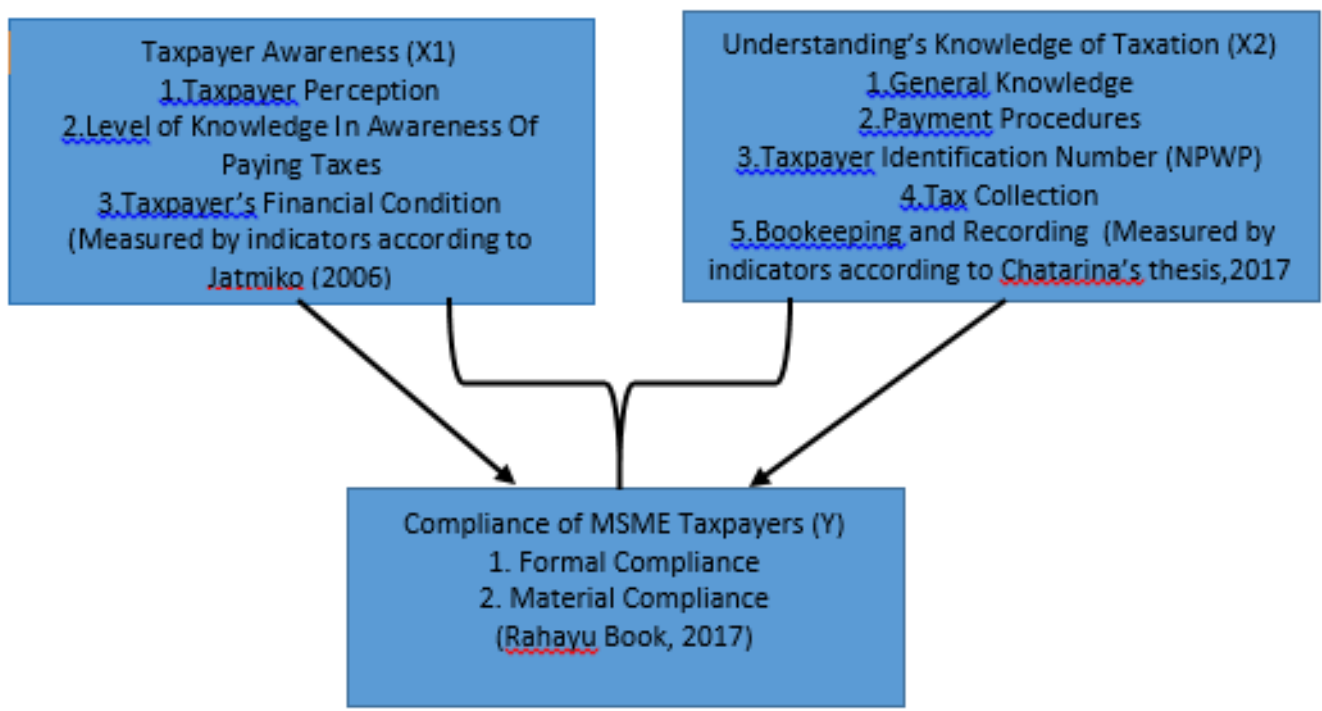


Effect of Taxpayer Awareness, Understanding's Knowledge of Taxation on Compliance of Small and Medium Micro Business Taxpayers at Pratama Tax Service Office Cibitung

Subagiyo, Nubaity, Islah, Hermawan, Junaidi

Hypothesis

1. The effects of taxpayer's consciousness regarding the compliance of taxpayer MSMEs, taxpayers, the higher the knowledge of the knowledge of the taxpayers in performing taxes, the higher the compliance of taxpayers in compliance with taxes. This was also supported by previous examinations that the knowledge of tax repayment had a positive and meaningful effect on the compliance of taxpayers. From Review at the beginning of the researchers could be concluded the following similarities:

H1: Allegedly that the knowledge of taxpayers has a positive impact on the compliance of UMKM taxpayers

2. The influence of tax knowledge views regarding the compliance of Taxpayers. Taxpayers Knowledge of understanding regarding tax regulations affected compliance with Tax MSMEs in Bekasi Regency (Pratama, 2019). From the reviews at the beginning of the researchers received the following allegations:

H2: Allegedly that knowledge of understanding of taxation has a positive impact on compliance with small and medium micro-medium micro companies (MSMEs)

3. Influence of taxpayer awareness, Understanding's Knowledge of taxation on compliance of MSME taxpayers

The results of this study are in line with the theory of planned behavior revealed by Ajzen (Rahmadhani et al., 2020), where this theory is influenced by attitude factors towards behavior and behavior control (Prawagis et al., 2016).

From the description above the researchers concluded the hypothesis as follows:

H3: Alleged taxpayer awareness, understanding and knowledge of taxation positively affect the compliance of msmes taxpayers.

\section{METHOD}

The type of analysis used in this study is quantitative. The quantitative analysis method can be interpreted such as the procedure for the analysis of the idea of positivism, used to examine certain populations or examples, the collection of information using objects to test the established suspicion (Sugiyono, 2019).

This type of analysis includes causal analysis. Causal research is a study that examines the variable engaging into a target that is studied more diverse causal, so that the part in this analysis has an independent and dependent variable (Bauer et al., 2021; Djaali, 2020). The researchers tested the impact of taxpayer's awareness, knowledge of understanding about taxation, regarding the compliance of micro, small, and small businesses recorded at the Pratama Cibitung Office Tax Office. This research uses accidental sampling procedures using 100 respondents.

\section{RESULT AND DISCUSSION}

a. Validity Test. Validity test is used to measuring validity or not a list of questions (Sari \& Wardani, 2016). The questionnaire is declared valid if the question or expression on the list of questions can express something that will be measured using a list of questions (Ghozali, 2016). Measurement of validity can be done using the relationship between the value of the item about 
Effect of Taxpayer Awareness, Understanding's Knowledge of Taxation on Compliance of Small and Medium Micro Business Taxpayers at Pratama Tax Service Office Cibitung

Subagiyo, Nubaity, Islah, Hermawan, Junaidi

using the value of the construct or variable value (Yani et al., 2020). From the impact of the research, it can be seen that the value of the part of the table in the design of $R$ tables is found 0.1654 and the $\mathrm{R}$ value is calculated to all items the part of the part in the list of questions is worth more than $\mathrm{r}$ table, and the significance value to all questions is less than 0.1 meaningful it can be concluded that linear regression analysis is valid or appropriate.

b. Reliability Test. Reliability testing aims to measure questionnaires that are indicators of variables (Ghozali, 2016; Yani et al., 2020). This reliability test uses the SPSS.23 program with cronbach's Alpha method (Perdana \& Dwirandra, 2020). Croanbach's Alpha is when obtained croanbach's Alpha value of less than 0.600 means bad, about 0.700 is accepted and more or equal to 0.800 is good. 1) If $\mathrm{r}$ alpha is positive and $\mathrm{r}$ alpha is $>0,600$, then the reliabel question is 2) If $r$ alpha negative and $r$ alpha $<0.600$, then the question is not reliable 3) $r$ alpha can be seen on reliability coefficient. Based on the results of reliability tests known cronbach's alpha value of $0.837,0.852,0.871$ this value is greater than the provision of 0.60 then it can be concluded that all question items totaling 24 items have a reliable or consistent nature.

c. Normality test, normality research intends to understand whether each cause is usually distributed or not (Ghozali, 2016; Sari \& Wardani, 2016). The normality test is needed because of the testing of other variables using estimates that the residual value follows the normal distribution. To test evidence that is usually distributed or not, can be found using a normal graph plot.

\begin{tabular}{lll}
\multicolumn{1}{c}{ One-Sample Kolmogorov-Smirnov Test } \\
Unstandardized Residual \\
$\mathrm{N}$ & \multicolumn{1}{c}{100} \\
Normal Parametersa,b & Mean &, 0000000 \\
& Std. Deviation & 3,17605405 \\
Most Extreme Differences & Absolute &, 046 \\
& Positive &, 040 \\
& Negative &,- 046 \\
Test Statistic & &, 046 \\
Asymp. Sig. (2-tailed) & & .200 \\
\hline
\end{tabular}

Data : Processed in SPSS v.23

Kolmogorov-Smirmov Test Results, have a significant Asymp value of 0.200 where the result shows a significant level greater than 0.1 . This means that the data is normally distributed.

d. Multikolinies Test, Multicolinies The test is to investigate whether there is a high relationship between the free variables in the multiple linear regression model (Ghozali, 2016). Multicolerity tests can be done by paying attention to the inflation component variance (VIF) or tolerance value. Tolerance value limit $\geq 0.10$ and vif $\leq 10$. The estimated results of the variance inflation factor (VIF) also show the same matter, with the VIF value for each taxpayer awareness variable of 1,975, the understanding and knowledge of taxation 1,975. So no independent variable has a VIF value of more than 10 . So this study did not occur multi-collocity between free variables.

e. Heteroscedasticity tests, scatterplot charts from this analysis can be seen, under heteroscedasticity testing are carried out to examine whether there are variance inequalities 
Effect of Taxpayer Awareness, Understanding's Knowledge of Taxation on Compliance of Small and Medium Micro Business Taxpayers at Pratama Tax Service Office Cibitung

Subagiyo, Nubaity, Islah, Hermawan, Junaidi

originating in former monitoring to another (Ghozali, 2016). The existence or absence of heteroscedasticity in this analysis can be seen from the plot chart.:

scatterplot

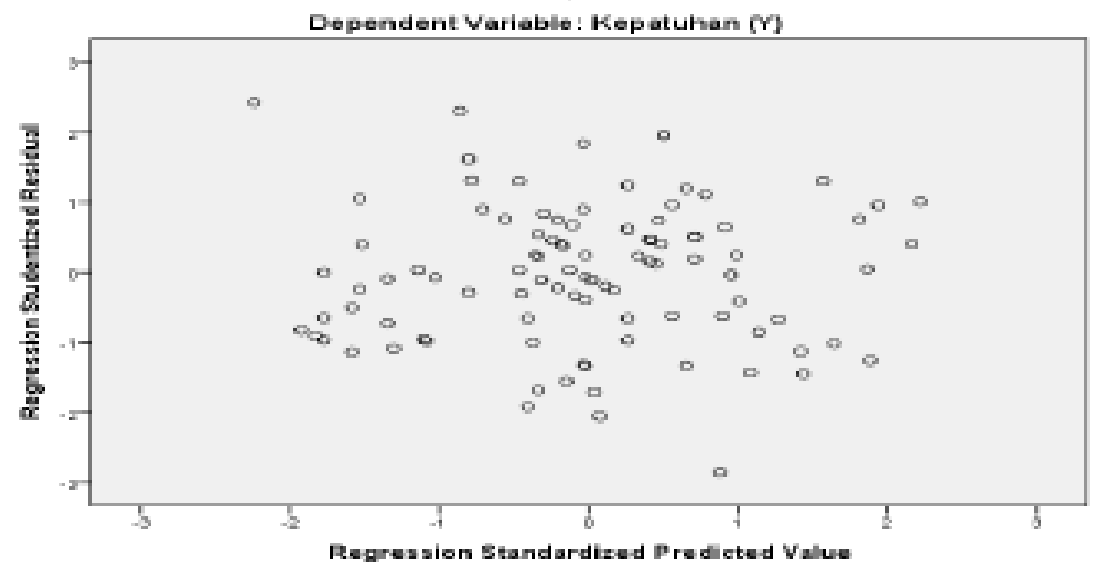

Scatterplot Heteroscedasticity test results show that the facts spread above and below the score 0 (zero) on the $\mathrm{Y}$ axis and there is no clear example near the spread of the fact. This means that there is no heterosaryity in the regression model. So it can be concluded that the inspection regression model is suitable to use to suspect the compliance of taxpayers belonging to the variables that affect it, namely Taxpayer Awareness and Tax Understanding and Knowledge.

f. Autocorrelation test, Autocoeration deviation in this study was tested with Durbin-Watson test (DW-test), the results of autokoleration can be seen in the following table:

$\begin{array}{llllll}\text { Model } & \mathrm{R} & \mathrm{R} & \begin{array}{l}\text { Adjusted } \\ \text { Square }\end{array} & \begin{array}{l}\text { Std. Error } \\ \text { R Square } \\ \text { of the } \\ \text { Estimate }\end{array} & \begin{array}{l}\text { Durbin- } \\ \text { Watson }\end{array} \\ 1 & 685 a & 470 & , 459 & 3,192 & 1,823\end{array}$

the above autocomeration test results show that the Durbin-Watson value of 1,823 corresponds to the Durbin-Watson table that in the lower limit range (dl) of 1.6337 and the upper limit (du) of 1.7152 and $k=2$, because the DW velue 1,823 is greater than the upper limit value (du) of 1.7152 and less than $4-1.6337=2.3662$, it can be concluded that there is no autocoleration in the regression model of taxpayer awareness, understanding and knowledge of taxation to taxpayer compliance.

g. T Test, Partial test or (t test) is used to test whether each independent variable namely Taxpayer Awareness (X1) and Tax Understanding and Knowledge (X2) has a positive influence and significance to dependent variables namely Partial Taxpayer Compliance (Y). The rule of decision-making in the $t$ test by formulating spss with a significant rate set at $10 \%$ is if the significant value is $>0.1$, then $\mathrm{Ho}$ is accepted and $\mathrm{Ha}$ is rejected, or the free variable cannot explain the bound variable or there is no influence between the variables tested and if the significance value $<0.1$, then $\mathrm{Ho}$ is rejected and $\mathrm{Ha}$ is accepted, or the free variable can explain the bound variable or there is an influence between the variables tested. 
Effect of Taxpayer Awareness, Understanding's Knowledge of Taxation on Compliance of Small and Medium Micro Business Taxpayers at Pratama Tax Service Office Cibitung

Subagiyo, Nubaity, Islah, Hermawan, Junaidi

\begin{tabular}{|c|c|c|c|c|c|}
\hline \multirow{3}{*}{ Model } & \multicolumn{5}{|c|}{ Coefficientsa } \\
\hline & \multicolumn{3}{|c|}{ Unstandardized Coefficients } & \multicolumn{2}{|c|}{ Standardized Coefficients } \\
\hline & & & & $t$ & Sig. \\
\hline & B & Std. Error & Beta & & \\
\hline (Constant) & 7,603 & 2,366 & & 3,213 & ,002 \\
\hline Kesadaran (X1) & 444 &, 096 & ,478 & 4,602 &, 000 \\
\hline Pemahaman dan & & & & & \\
\hline Pengetahuan (X2) & .279 & .112 & .259 & 2.495 & .014 \\
\hline
\end{tabular}

Source : SPSS Data Processing v.23

1) The significance value for taxpayer awareness variables is 0.000 or less than 0.1 . T table of 1,660 and thitung 4,602. So thitung $>$ ttabel, then Ho rejected or H1 accepted. Taxpayer-imposed variables significantly affect taxpayer compliance.

2) The significance value for variable understanding and knowledge of taxation is 0.014 or less than 0.1. 1,660 and thitung 2,495. So thitung $>$ ttabel. Then Ho was rejected or H2 accepted. Variable understanding and knowledge of taxation significantly affects taxpayer compliance.

h. Test F Statistical test $\mathrm{F}$ aims to determine the influence of joint or simultaneous independent variables on dependent or bound variables. The criteria used are if a significant level of $\mathrm{F}>0.1$ or Fcalculate $<$ Ftabel, then $\mathrm{Ho}$ is accepted and if a significant level of $\mathrm{F}<$ 0.1 or Fcalculate $>$ Ftabel, then Ho is rejected.

\section{ANOVA}

$\begin{array}{lllllll} & \text { Model } & \text { Sum of Squares } & \text { df } & \text { Mean Square } & \text { F } & \text { Sig. } \\ \text { Regression } & 876,161 & 2 & 438,080 & 42,991 & , 000 \mathrm{~b} \\ & \begin{array}{l}\text { Residual } \\ \text { Total } 1868,429\end{array} & 97 & 10,190 & & \\ & \end{array}$

Source : SPSS Data Processing v.23

it is known that a significant value of $0.000<0.1$ Fhitung value of $42,991>$ Ftabel 3.09 then the regression analysis model is significant therefore the regression model can be used to predict taxpayer awareness and understanding and knowledge of taxation. In this case it means that independent variables i.e. it can be concluded that there is no autocoleration in the regression model of taxpayer awareness.

i. The Determination Coefficient Test (R2), of the Determination Coefficient basically measures how far the model can go in applying variations of related variables. The $\mathrm{R} 2$ value is between 0 and 1 . The small $\mathrm{R} 2$ value is meaningful to the ability of free variables to explain the related cause is very limited. The value close to 1 part in the free variable submits all the data needed to estimate the cause of related (Ghozali, 2016). From the results of the table obtained R2 value of 0.470 means the percentage of contribution of variable influence $\mathrm{X} 1$ and $\mathrm{X} 2$ to $\mathrm{Y}$ by $47 \%$. While the remaining $53 \%$ is affected or explained by other countless variables in this model of analysis.

j. Multiple regression analysis, multiple regression analysis is the analysis of the internship between two or more independent variables with the dependent variable. This analysis is used to assign the intercourse between the independent variables and dependent variables. 
Effect of Taxpayer Awareness, Understanding's Knowledge of Taxation on Compliance of Small and Medium Micro Business Taxpayers at Pratama Tax Service Office Cibitung

Subagiyo, Nubaity, Islah, Hermawan, Junaidi

Based on the coefficient table above, it can be seen the value of Unstandardized Coefficients and can be concluded as follows:

1) Constant of 7,603 means that if Taxpayer Awareness (X1), Understanding and Knowledge of Taxation (X2) is 0 , Taxpayer Compliance (Y) is worth 7,603

2) The coefficient of taxpayer awareness variable regression (X1) is 0.444 , meaning that if Taxpayer Awareness increases by 1 then Taxpayer Compliance (Y) increases by 44.4\% assuming other independent variables of fixed value. The positive value coefficient is meaningful that there is a positive poutage between taxpayer's awareness and taxpayer compliance, the higher the taxpayer's awareness, the more and more taxpayer compliance increases.

3) The coefficient of variable regression of Understanding and Knowledge of Taxation (X2) amounted to 0.279 , meaning that if the understanding and knowledge of taxation increased by 1 then taxpayer compliance $(Y)$ increased by $27.9 \%$ assuming other independent variables of fixed value. The coefficient of positive value is meaningful that there are positive internships between understanding and knowledge regarding taxation and taxpayers.

\section{CONCLUSION}

Based on the results of the study and discussion obtained conclusions:

1) In line with the hypothesis conducted by taxpayer awareness researchers have a positive and significant effect on the compliance of taxpayers of MSMEs personal persons in the Tax Service Office Pratama Cibitung. The amount of taxpayer awareness of MSMEs' personal persons on taxpayer compliance at the Pratama Cibitung Tax Service Office was $31.55 \%$.

2) In line with the allegations carried out by tax researchers and tax knowledge have a positive and significant impact on the compliance of MSME taxpayers at the Cibitung Pratama Tax Office. The number of impacts of understanding of taxes and knowledge of the compliance of UMKM taxpayers in the Tax Service Office pratama Cibitung by $15.41 \%$.

3) In line with the hypothesis conducted by taxpayer awareness researchers and tax understanding and knowledge Has a significant impact on the compliance of MSME taxpayers at the Cibitung Pratama Tax Office. The number of impacts of taxpayers and understanding and knowledge of taxpayers for compliance with MSME taxpayers at the Pratama Cibitung Tax Service Office numbered 47\%. While the remaining 53\% is influenced or explained by other countless variables in this research model

\section{REFERENCE}

Andreas, \& Savitri, E. (2015). The Effect of Tax Socialization, Tax Knowledge, Expediency of Tax ID Number and Service Quality on Taxpayers Compliance with Taxpayers Awareness as Mediating Variables. Procedia - Social and Behavioral Sciences, 211, 163-169. https://doi.org/10.1016/j.sbspro.2015.11.024 
Effect of Taxpayer Awareness, Understanding's Knowledge of Taxation on Compliance of Small and Medium Micro Business Taxpayers at Pratama Tax Service Office Cibitung

Subagiyo, Nubaity, Islah, Hermawan, Junaidi

Barigozzi, F., Cremer, H., \& Roeder, K. (2019). Till taxes do us part: Tax penalties or bonuses and the marriage decision. European Economic Review, 118, 37-50.

https://doi.org/10.1016/j.euroecorev.2019.05.001

Batrancea, L., Nichita, A., Olsen, J., Kogler, C., Kirchler, E., Hoelzl, E., Weiss, A., Torgler, B., Fooken, J., Fuller, J., Schaffner, M., Banuri, S., Hassanein, M., Alarcón-García, G., Aldemir, C., Apostol, O., Bank Weinberg, D., Batrancea, I., Belianin, A., ... Zukauskas, S. (2019). Trust and power as determinants of tax compliance across 44 nations. Journal of Economic Psychology, 74, 102191. https://doi.org/10.1016/j.joep.2019.102191

Bauer, G. R., Churchill, S. M., Mahendran, M., Walwyn, C., Lizotte, D., \& Villa-Rueda, A. A. (2021). Intersectionality in quantitative research: A systematic review of its emergence and applications of theory and methods. SSM - Population Health, 14, 100798. https://doi.org/10.1016/j.ssmph.2021.100798

Chaudhry, N. (2021). Tax aggressiveness and idiosyncratic volatility. The North American Journal of Economics and Finance, 58, 101488. https://doi.org/10.1016/j.najef.2021.101488

Cozmei, C., \& Rusu, M. (2015). The EU Tax Treatment Competition for Knowledge Based Capital - The Special Case of R\&amp;D. Procedia Economics and Finance, 32, 817-825. https://doi.org/10.1016/S2212-5671(15)01523-3

Damayanti, T. W., Sutrisno, Subekti, I., \& Baridwan, Z. (2015). Trust and Uncertainty Orientation: An Efforts to Create Tax Compliance in Social Psychology Framework. Procedia - Social and Behavioral Sciences, 211, 938-944. https://doi.org/10.1016/j.sbspro.2015.11.124

Djaali. (2020). Metodologi Penelitian Kuantitatif(1st ed.). Bina Aksara Publishing. https://openlibrary.telkomuniversity.ac.id/home/catalog/id/167948/slug/metodologipenelitian-kuantitatif.html

Ernita, K., \& Sudjiman, P. E. (2021). Pengaruh Penggunaan E-Tax Terhadap Kepatuhan Wajib Pajak (Studi pada Kantor Pelayanan Pajak Pratama Cibitung). Jurnal Ekonomi Dan Bisnis EKONOMIS, 14(1), 3-18. https://jurnal.unai.edu/index.php/jeko/article/view/2499

Ghozali, I. (2016). Aplikasi Analisis Multivariete dengan Program IBM SPSS 23 (I. Ghozali (ed.); 8th ed.). Badan Penerbit Universitas Diponegoro.

http:/ / kin.perpusnas.go.id/DisplayData.aspx?pId=218217\&pRegionCode=UN11MAR\&p ClientId $=112$

Hajawiyah, A., Suryarini, T., Kiswanto, \& Tarmudji, T. (2021). Analysis of a tax amnesty's effectiveness in Indonesia. Journal of International Accounting, Auditing and Taxation, 44, 100415. https://doi.org/10.1016/j.intaccaudtax.2021.100415

Iyer, G. S., \& Kaszak, S. E. (2021). What do taxpayers prefer: Lower taxes or a better year-end position? A research note. Journal of Accounting and Public Policy, 106902. https://doi.org/10.1016/j.jaccpubpol.2021.106902

Machmudah, N. (2020). Pengaruh Tarif Pajak, Pengetabuan Perpajakan, dan Sanksi Pajak Terhadap Kepatuhan Pembayaran Pajak UMKM [Universitas Ahmad Dahlan]. http://eprints.uad.ac.id/20941/

Melando, N., \& Waluyo, W. (2013). Pengaruh Pelayanan Fiskus, Persepsi Atas Efektivitas Sistem Perpajakan, Pengetahuan Pajak, Dan Kesadaran Wajib Pajak Terhadap Kepatuhan Wajib Pajak Orang Pribadi. Jurnal ULTIMA Accounting, 5(2), 17-37. 
Effect of Taxpayer Awareness, Understanding's Knowledge of Taxation on Compliance of Small and Medium Micro Business Taxpayers at Pratama Tax Service Office Cibitung

Subagiyo, Nubaity, Islah, Hermawan, Junaidi

https://doi.org/10.31937/akuntansi.v5i2.150

Perdana, E. S., \& Dwirandra, A. A. N. . (2020). Pengaruh Kesadaran Wajib Pajak, Pengetahuan Perpajakan, dan Sanksi Perpajakan Pada Kepatuhan Wajib Pajak UMKM. E-Jurnal Akuntansi, 30(6), 1458. https://doi.org/10.24843/EJA.2020.v30.i06.p09

Pratama, E. J. (2019). Pengarub Kesadaran, Pengetabuan Perpajakan, Sanksi, Pelayanan Fiskus, dan Perubahan Tarif terbadap Kepatuban Wajib Pajak Orang Pribadi Pelaku UMKM (Studi Empiris Pada Kantor Pelayanan Pajak Pratama Serpong) [Universitas Multimedia Nusantara]. https://kc.umn.ac.id/10450/

Prawagis, F. D., Zahroh, Z. A., \& Mayowan, Y. (2016). Pengaruh Pemahaman atas Mekanisme Pembayaran Pajak, Persepsi Tarif Pajak dan Sanksi Pajak terhadap Kepatuhan Wajib Pajak UMKM (Studi Pada Wajib Pajak Yang Terdaftar di KPP Pratama Batu). Jumal Mabasiswa Perpajakan, 10(1).

http://perpajakan.studentjournal.ub.ac.id/index.php/perpajakan/article/view/293

Rahayu, D. P. (2019). Faktor-faktor yang Mempengaruhi Kepatuhan Sukarela Wajib Pajak. Jurnal Akuntansi Indonesia, 8(1), 17. https://doi.org/10.30659/jai.8.1.17-25

Rahmadhani, S. R., Cheisviyanny, C., \& Mulyani, E. (2020). Analisis Kepatuhan Pajak Pelaku UMKM Pasca Penerbitan Peraturan Pemerintah Nomor 23 Tahun 2018. Jurnal Ekesplorasi Akuntansi, 2(1), 2537-2553. https://doi.org/10.24036/jea.v2i1.228

Saad, N. (2014). Tax Knowledge, Tax Complexity and Tax Compliance: Taxpayers' View. Procedia - Social and Behavioral Sciences, 109, 1069-1075. https://doi.org/10.1016/j.sbspro.2013.12.590

Sari, N., \& Wardani, R. (2016). Pengolahan dan Analisa Data Statistika (1st ed.). Deepublish Publisher. https://opac.perpusnas.go.id/DetailOpac.aspx?id=1143935

Savitri, E., \& Musfialdy. (2016). The Effect of Taxpayer Awareness, Tax Socialization, Tax Penalties, Compliance Cost at Taxpayer Compliance with Service Quality as Mediating Variable. Procedia - Social and Behavioral Sciences, 219, 682-687. https://doi.org/10.1016/j.sbspro.2016.05.051

Shafi, M., Liu, J., \& Ren, W. (2020). Impact of COVID-19 pandemic on micro, small, and medium-sized Enterprises operating in Pakistan. Research in Globalization, 2, 100018. https://doi.org/10.1016/j.resglo.2020.100018

Sinuhaji, A. A. (2019). Pengaruh Pengetabuan Pajak, Pelayanan Fiskus, Sosialisasi Dan Sanksi Pajak Terhadap Kepatuhan Wajib Pajak Orang Pribadi (Studi Kasus Di KPP Pratama Serpong [Indonesia Banking School]. http://repository.ibs.ac.id/125/

Sugiyono. (2019). Metode Penelitian Kuantitatif Kualitatif dan R\&D (I). Alfabeta. https://cvalfabeta.com/product/metode-penelitian-kuantitatif-kualitatif-dan-rd-mpkk/

Susanti, N., \& Widajatun, V. W. (2021). MSMEs Understanding of Taxation During the COVID-19 Pandemic. Journal of Innovation and Community Engagement, 2(1), 35-46. https://doi.org/10.28932/jice.v2i1.3689

Syuhada, A., \& Gambetta, W. (2013). Online Marketplace for Indonesian Micro Small and Medium Enterprises Based on Social Media. The 4th International Conference on Electrical Engineering and Informatics (ICEEI 2013), 446-454.

https://doi.org/https://www.sciencedirect.com/science/article/pii/S221201731300368X 
Effect of Taxpayer Awareness, Understanding's Knowledge of Taxation on Compliance of Small and Medium Micro Business Taxpayers at Pratama Tax Service Office Cibitung

Subagiyo, Nubaity, Islah, Hermawan, Junaidi

Tambunan, T. T. H. (2019). Micro and Small Industries and the Use of Internet: Findings from Indonesian. Jurnal Ekonomi Indonesia, 8(2), 203-224. https://doi.org/10.52813/jei.v8i2.20

von Brasch, T., Cappelen, Å., Hungnes, H., \& Skjerpen, T. (2021). Modeling R\&amp;D spillovers to productivity: The effects of tax credits. Economic Modelling, 101, 105545. https://doi.org/10.1016/j.econmod.2021.105545

Widiastuti. (2017). Pengaruh Kualitas Pelayanan Terhadap Kepatuhan Wajib Pajak Orang Pribadi dengan Kepuasan Sebagai Variabel Intervening Kantor Pelayanan Pajak Pratama Cibitung. Jurnal Akuntansi Bisnis Pelita Bangsa, 02(01), 1-15.

https://journal.lppmpelitabangsa.id/index.php/akubis/article/view/110

Yani, A., Suratman, D., \& Darma, Y. (2020). Analisis Data Statistik: Sebuah Pendekatan Praktis Pengolahan Statistik Bermuatan Karakter (1st ed.). Graha Ilmu.

http://grahailmu.id/product/analisis-data-statistik-sebuah-pendekatan-praktis-pengolahanstatistik-bermuatan-karakter/ 